\title{
WOJCIECH KOSIOR*
}

(Jagiellonian University in Kraków)

\section{Book review: \\ Y. Petrovsky-Shtern, The Golden Age Shtetl: A New History of Jewish Life in East Europe, Princeton Univ. Press, Woodstock Oxfordshire 2014}

The present tome is one of the most recent publications from the Princeton University Press concerning Eastern European Jewry. The main thrust of the work is that from the end of the $18^{\text {th }}$ up till the half of the $19^{\text {th }}$ century shtetl was a thriving and vibrant Jewish community, experiencing the peak of its economic and cultural development. In short, shtetl was a Polish private town, belonging to a Catholic magnate, administrated by the tsarist empire, yet economically driven by the Jews. Although a direct comparison is nowhere present, associations with the convivenza of the Iberian Peninsula emerge. Analogically, the volume presents the golden age of shtetl as a common enterprise with each of the parties making a contribution. The book in turn is advertised as "challenging popular misconceptions of the shtetl as an isolated, ramshackle Jewish village stricken by poverty and pogroms"1. While acknowledging the work of the previous historians, Petrovsky-Shtern notes that the Russian and Ukrainian sources describing the phenomenon have remained for a long time unrecognised for their scientific value and, as he him-

\footnotetext{
* Faculty of Philosophy, Centre for Comparative Studies of Civilisations Jagiellonian University in Kraków, Poland e-mail: wojciechkosior@o2.pl

${ }^{1}$ [Online], http://press.princeton.edu/titles/10186.html [access: 21 VI 2014].
} 
self puts it: "to gain access to these documents, I sometimes disguised myself as a Ukrainian clerk, a Soviet speleologist and a Polar explorer"2.

The book is divided into ten chapters structured around several issues. In the first section (Russia Discovers Its Shtetl) the author explains how the study of shtetl came into being and credits the Russian cartographers: "an anonymous, modest, and diligent group of clerks" who "treated what they saw with the empathy of collectors discovering for the first time what the Russian Empire had come to own"3. The core of Petrovsky-Shtern's argument is unravelled in chapters two to four (Lawless Freedom, Fair Trade and The Right to Drink) which paint a complex picture of the legal and economic backbone of shtetl. Due to the tense situation between Russia and western Europe, there have been numerous restrictions on imported goods, especially these coming from France. The rigidness of the Russian law imposed on the shtetl on the one hand and the high demand for the said goods on the other contributed to the development of contraband regulated by an alternative set of rules fuelled by bribes and sealed with kvitki - the unofficial bills of smugglers. In other words, "while Russian bureaucracy was trying to tame the shtetl trade, the Jews began taming Russian bureaucracy" ". Moreover, the author demonstrates that it was normal to find smuggling groups combined of Russians, Poles, Ukrainians and Jews alike, as they all had to cooperate in these particular conditions. Paradoxically then, smuggling constituted a specific kind of intercultural dialogue. Chapters five and six (A Violent Dignity and Crime, Punishment, and a Promise of Justice) show, that this duality of laws was also reflected in other aspects of the legal framework. Given the lack of effective rules and executive powers, the inhabitants of shtetl had to come up with some alternative system and at the end it was violence that constituted the common language of shtetl. It is important to note that the author goes beyond the pattern of Eastern European anti-Semitism and presents the Jews as equally engaged in the conflict: "before they mastered the Slavic language, they mastered the shared language of the Slavic culture". ${ }^{5}$ In addition to this, Petrovsky-Shtern does not refrain from bringing up other facts concerning Jewish violence: "Jews reaffirmed their religion by putting Christianity down, reversing what was regularly done to them by Christians" ${ }^{\prime 6}$. In other words, the Jews had been as strong and capable as any other

\footnotetext{
${ }^{2}$ Y. Petrovsky-Shtern, The Golden Age Shtetl: A New History of Jewish Life in East Europe, Princeton University Press, Woodstock Oxfordshire 2014, p. 7.

${ }^{3}$ Ibidem, p. 36-37.

${ }^{4}$ Ibidem, p. 66.

${ }^{5}$ Ibidem, p. 164.

${ }^{6}$ Ibidem, p. 166. Moreover, as he puts it in one of the interviews: "Violence - verbal, rhetorical, physical - is a typical and normative modus vivendi of the shtetl. Anybody who
} 
party involved and the author substantiates this claim with police reports of the Jewish crimes ${ }^{7}$.

Having dealt with the economic and legal matters, the author takes his readers inside Jewish houses and alcoves in chapter seven (Family Matters), where he explores the issues of morality and intimacy. Petrovsky-Shtern shows that the performing mitzvot as participation in the large scale divine plan went far beyond the marketplace. One cannot but admire the inventiveness of the Hassidic masters that "could have legitimately argued that immersing oneself in the blatant physicality of the tavern was incompatible with Judaic piety but instead they chose to uplift and spiritualize its pleasures" ${ }^{\prime \prime}$. The same applies to "kosher sex" intended for procreation and fulfilling the commandment: "pirya ve-rivya iz di beste mitzve" as the Yiddish proverb goes. Thus the corporeal enjoyment has been transformed into a spiritual quest. The adaptation of the Jews to living in the Eastern European diaspora is the subject of chapters eight and nine (Open House and If I Forget Thee). On the one hand, there had been numerous rules concerning the settlements which resulted in the distinctive nature of the Jewish houses. Restricted in space and form, the Jewish architects had to explore other options for expanding their dwellings while simultaneously keeping them capable of securing the proper execution of particular halakhic obligations. On the other hand, the shtetl Jews perceived themselves as the holy community on earth and accordingly strived to transform their space into one resembling Jerusalem with the local synagogue substituting the temple.

Chapter ten (The Books of the People) aptly shows how the Hassidic movement made use of classical Jewish literature. Although the publishing houses provided the Jewish society first and foremost with traditional works, these were often accompanied by Hassidic commentaries. This applied equally to siddurs, kabbalistic treatises and halakhic codices and at the same time allowed both to demonstrate "the absolute centrality of Hasidism to the Judaic

\footnotetext{
wants to partake of it, partakes of it. Ukrainians know Yiddish curses, Jews know Ukrainian curses. We are dealing with equal opportunity violence". L. Falk, Turning the Shtetl Upside Down: An Interview with Yohanan Petrovsky-Shtern, [online], http://www.yivo.org/ blog/ index.php/ 2014/ 03/ 14/ turning-the-shtetl-upside-down-an-interview-with-yohananpetrovsky-shtern/ [access: 21 VI 2014].

${ }^{7}$ Another common view holds that the Jews stood out from the society. Meanwhile, as the police descriptions furnished by the author show this was not the case and telling between the Jew and Ukrainian or a Pole on the "face value" was practically impossible. Y. Petrovsky-Shtern, op. cit., p. 188-190.

${ }^{8}$ Ibidem, p. 130.

${ }^{9}$ Ibidem, p. 240.
} 
tradition" and to add "Hasidic flavor to the traditional books"10. The Hassidic rabbis themselves enjoyed a great deal of respect as is corroborated by the effectiveness of their excommunications. The examples show that the herem was something one had to take into account as "an excommunicated Jew was not allowed in the synagogue, butchers would not sell him kosher meat, his wife could not use the ritual bath and was sexually unavailable to her husband. Rejected by local families, their children would be outcasts on the shtetl street" ". The author also advances an interesting remark that the absolute Russian monarchy was reflected in the religious sphere. Hassids imitated the Russian tsarist power so that the figure of a tzaddik paralleled that of a tsar. Analogically, the form and structure of the Hassidic courts with their dynasties were "the Jewish doubles of the Romanovs" and as the author puts it: "one doesn't imitate what one dislikes" 12 . Nevertheless, ultimately it was Russia that disliked the Jews. In the concluding part (The End of the Golden Age), the author elaborates on the factors which led to the decline of the shtetl. The fifty-year period of productivity and stability which presented economic opportunities for the Russian Empire had been ultimately ruined by the ideology of nationalism and chauvinism. As the author puts it: "it was too abundant, vigorous, and independent for the Russian regime to reconcile with" ${ }^{\text {" I I }}$ addition to this other factors have also been at play: the administrational changes, the development of the railway roads which marginalised the smaller towns or simply natural disasters like fires.

In conclusion, every chapter is a piece of a puzzle. The author gradually portrays the image of shtetl and the descriptions of the broader phenomena are paired with particular cases exemplifying more general notions. Finally, everything comes together - economics, morality, religion - in one coherent picture. The text is fluently written ${ }^{14}$; the author maintains the balance between vibrant, almost anecdotal narration and solid methodology relying on the numbers derived from historical sources. As a result, the book is exceptionally colourful - not only due to the richness and vividness of the stories contained within but also because of its visual aspect. The text is supplemented by high quality pictures presenting the unknown treasures of the shtetl

${ }^{10}$ Ibidem, p. 311 . Worth noting is that this by no means was a new invention. A similar method had been resorted to by rabbi Moshe Isserles who relied on the popularity of Shulkhan Arukh in promoting his own halakhic opinions.

${ }^{11}$ Ibidem, p. 82.

${ }^{12}$ Ibidem, p. 43-44.

${ }^{13}$ Ibidem, p. 55.

${ }^{14}$ The only serious editorial drawback is the application of the end-notes rather than much more convenient foot-notes. 
Jewry thus allowing the reader to better comprehend the reality of the period. In addition to this, the publication contains some of the author's works thus contributing to the esthetical pleasure of the reader ${ }^{15}$. Of special significance is the cover picture, which

[...] shows that the shtetl is very much a self-contained entity. It's a «yin-yang» $[\ldots]$ You have a woman with a jar of milk, or honey, anything that has something to do with physicality - and you have a topsy-turvy man with a book, with his spirituality. These two opposites cannot exist without one another. You can look at it both ways, turning the picture upside down. [...] Since everything is topsy-turvy, and mutually complementary, it does convey an important principle - after all I'm turning upside down received concepts with which we look at the shtet ${ }^{16}$.

${ }^{15}$ See also the online gallery. [Online], http://www.petrovsky-shtern.com [access: $20 \mathrm{VI}$ 2014].

${ }^{16}$ L. Falk, op. cit. 